\title{
FAUNA OF MOSQUITO LARVAE (DIPTERA: CULICIDA) IN ASIR PROVENCE, KINGDOM OF SAUDI ARABIA
}

\author{
By \\ HAMDY A. AL ASHRY ${ }^{1}$, MOHAMED A. KENAWY ${ }^{*}$ \\ AND MOHAMMED SHOBRAK ${ }^{3}$
}

Environmental Balance Co., Alrawdah District, Jeddah, Kingdom of Saudi Arabia ${ }^{1}$, Department of Entomology, Faculty of Science, Ain Shams University, Cairo 11566, Egypt $^{2}$, Biology Department, Science College, Taif University, Taif 21974, Kingdom of Saudi Arabia ${ }^{3}$ ("correspondence Dr. Kenawy, mohamedkenawy85@yahoo.com.)

\begin{abstract}
An entomological survey was undertaken for one year to update the mosquito fauna of Asir Region, Kingdom of Saudi Arabia. A total of 31 species of 8 genera were reported of which genus Culex (55\%) was the most common. Most of collected larvae (59\%) belonged to genus Culex (+ Lutzia) followed by Culiseta (26\%), Anopheles (13\%) and Aedine spp. (2\%). Cx. pipiens $(39 \%)$ and Cs. longiareolata (26. \%) were generally the most abundant of all collected larvae. Of the Anopheles spp., An. dthali was common (40\%), of Culex spp., $C x$. pipiens was predominating $(66 \%)$ and of Aedine spp., St. aegypti was predominating (71\%). Four species: An. fluviatilis, $C x$. mattinglyi, $C x$. arbieeni and $C x$. mimeticus were new reports in Asir Region and Cx. wigglesworthi recorded for the first time from the kingdom. Larvae were more common in low- and highlands than in the moderately altitude areas. In general all species prefer stagnant water but with the exception of Aedine larvae (altogether), the other species prefer presence of algae, vegetation and shade and absence of turbidity (except Culex spp.). A total of 98 different forms of association were reported of which 9 forms were common. All genera breed year round with peaks of abundance during spring for Anopheles spp. and Culex spp. and during winter for Aedine spp. and Cs. longiareolata. A complete list of mosquito fauna of Asir Region comprising $45 \mathrm{spp}$. was presented based on the present and previous surveys. The study concluded that the occurrence and prevalence of mosquito species mainly the disease vectors in Asir carry the thread of maintaining and transmission of several mosquito-borne diseases.
\end{abstract}

Key words: Mosquito fauna, Mosquito larvae, Relative abundance, Breeding water characteristics, Seasonal abundance, Asir Province, Saudi Arabia.

\section{Introduction}

Asir Province $\left(19^{\circ} 0^{\prime} \mathrm{N}, \quad 43^{\circ} 0^{\prime} \mathrm{E}\right.$ to $19.000^{\circ} \mathrm{N}, 43.000^{\circ} \mathrm{E}$ ) is located in the southwest of Saudi Arabia sharing a short border with Yemen. It has an area of $81,000 \mathrm{~km}^{2}$ and a population of $1,913,392$ (2010 Census). Administratively, the Province comprises 12 Governorates and its capital is Abha. Geographically, Asir is situated on a high plateau consists of the highlands that rise to almost 3,000 meters at Jebel Sawdah near Abha which is the extension of the Sarawat mountains parallel to the Red Sea and a narrow sandy coastal strip of lowlands known as Tehamah Plain. The Tehamah Plain is considered to be a geographic extension of the Jizan Region. The area receives more rainfall than the rest of the country. The average annual rainfall in the highlands ranges from 300 to 500 millimeters (12 to 20 inches) and is falling in two rainy seasons, the chief one being in March and April with some rain in the summer. Temperatures are very extreme and in the highlands are generally lower than the other part of the Region. The coastal plain zone is generally characterized by lower rainfall and high temperature and $\mathrm{RH}$.

During the last decade (2000-2010), 16 mosquito surveys were conducted in the Kingdom of Saudi Arabia, of which 6 were focused to the southwestern Region, in particular the Asir Region due to the 
epidemic of the Rift Valley fever (RVF) in 2000.

The distribution of mosquitoes in several regions of Saudi Arabia was reported by Mattingly and Knight, 1956; Zahar, 1974; Büttiker, 1981; Wills et al, 1985; AlSeghayer et al, 1999; Juppet al, 2002; Abdoon and Alshahrani, 2003; Alahmed et al., 2007; 2009; Al Ghamdi et al, 2008; AIAli et al, 2008; Al Ahmed et al, 2010; Ahmed et al, 2011 and Alahmed, 2012. Moreover, mosquitoes were surveyed in Asir Region or generally in the south western area by some workers. Abdullah and Merdan (1995) reported 9 mosquito species: 4 Anophelines, 3 Culicines, 1 Aedine and Culiseta subochrea in Asir. Miller et al. (2002) carried out a survey following the outbreak of RVF in Asir to assess the potential mosquito vectors in the Region and get virus isolate from Ae. vexans arabiensis females collected near the city of Muhayil. In addition, the authors collected 5 Aedes, 2 Anopheles, 4 Culex species. Abdoon and Alshahrani (2003) studied the prevalence and distribution of Anopheline mosquitoes in malaria endemic areas of Asir Region and reported 7 species. Marvin et al. (2003) conducted entomological surveillance in Asir, Jizan, and Makkah Regions following the appearance of RVF in Asir and collected Aedes (Stegomyia) unilineatus from Muhayil and near Rejal Almaa which represented the first record of this species from the Arabian Peninsula. Abdoon (2004) recorded for the first time three afrotopical Culex species in Asir Region.

In Saudi Arabia, several mosquito species are important as vectors of diseases. The most common mosquito-borne diseases include dengue (Fakeeh and Zaki, 2001; 2003; Ayyub et al, 2006; Khan et al, 2008), filariasis (Sebai et al, 1974; Omar, 1996), malaria (Warrel, 1993; Al-Seghayer et al, 1999; Abdoon and Alshahrani, 2003) and RVF (Jupp et al, 2002; Miller et al, 2002;
Al-Hazmi et al, 2003; Balkhy and Memish, 2003; Madani et al, 2003).

For the past few decades, Saudi Arabia has witnessed tremendous advances in social development and urbanization in almost all Regions (Alahmed, 2012; Abdullah and Merdan, 1995) which presumably have affected the insect fauna, particularly mosquitoes (Al Ahmed et al, 2010).

The present work was undertaken to update and study the distribution and some ecological aspects of mosquitoes in Asir Region.

\section{Materials and Methods}

The study included a total of 24 sites in 12 localities representing 8 out of the 12 Governorates of Asir Province (Fig. 1). The coordinates and elevation above sea level were recorded for each study site using a global positioning system (GPS) unit. The survey was carried out monthly (June 2009 to May 2010) in Abha "18 $13^{\prime} 1 " \mathrm{~N}$, $42^{\circ} 30^{\prime} 19^{\prime \prime} \mathrm{E}^{\prime \prime}$ (Abha dam and valley), Bishah $" 20^{\circ} 0^{\prime} 0^{\prime \prime} \mathrm{N}, 42^{\circ} 36^{\prime} 0^{\prime \prime} \mathrm{E}^{\prime}$ (Sheep market and Northern belt), Muhayil "18० 31' 590" N, 041 57' 899" E" (Hela valley) and Al Namas " $19^{\circ} 07^{\prime} 12^{\prime \prime} \mathrm{N}, 42^{\circ} 07^{\prime} 48^{\prime \prime} \mathrm{E}^{\prime \prime}$ (Tanomah dam and valley, Al mehfar resort and Red mountain valley). The other Governorates: Sarat Abidah " $18^{\circ} 00^{\prime} 852^{\prime \prime} \mathrm{N}, 043^{\circ} 09^{\prime} \mathrm{E}^{\prime \prime}$ (Sarat Abidah city, Al Goba dam and El Raboaa), Rejal Almaa "18 $18^{\circ}$ '590" N, $042^{\circ}$ 16' 538" E" (Rejal Almaa city), Balqarn "19 33' 763" N, 041 56' 954" E" (Al Kobri village and Balqarn valley) and Tathleth

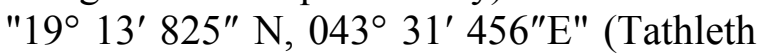
city) were infrequently surveyed (twice or three times during the year period).

In each site, inspections of the water bodies for mosquito larvae were carried out by using a plastic dipper, $125 \mathrm{~mm}$ in diameter with a $90 \mathrm{~cm}$ wooden handle. Three samples of 10 dips per breeding site were taken. Collected larvae were placed in labeled plastic bags and transported to the laboratory in an ice box containing cold water to prevent overheating. At the laboratory, $3^{\text {rd }}$ and $4^{\text {th }}$ larval instars were 
identified according to published keys of Hopkins (1952), Mattingly and Knight (1956) and Hardback (1985; 1988).

Along with larval collection, the natural characteristics of the breeding water were recorded as present or absent and included: algae, aquatic vegetation, shade, turbidity due suspended particles and movement. The frequency of occurrence (\%) of each reported species related to the presence or absence of such characters were examined and analyzed by Chi-squared test. The ranges of associated species with the most frequent species were calculated. The seasonal abundance of the different genera of the reported species was also examined. Based on the reported species in this survey and those in previous reports, a complete list of mosquito fauna of Asir Region was presented.

\section{Results}

A total of 31 species were reported (Tab. 1): 8 Anopheles spp. (25.81\%), 17 Culex spp. $(54.84 \%)$ and one species each of Lutzia (= Culex), Aedimorphus (=Aedes), Fredwardsius (=Aedes), Ochlerotatus, Stegomyia (=Aedes) and Culiseta. A total of 7247 larvae were collected, most of them (4304: 59.39\%) belonged to genus Culex $(+$ Lutzia) followed by Culiseta (1896: 26.16\%), Anopheles (942: 13\%) and Aedes as represented by Aedes, Aedimorphus, Fredwardsius, Ochlerotatus and Stegomyia (105: 1.45\%). Culex pipiens (2827 larva: 39.01\%) and Cs. longiareolata (1896 larva: $26.16 \%$ ) were generally the most abundant of all species. Of the Anopheles spp., An. dthali was common (40.13\%: 378/942 larva) while $A n$. culicifacies and $A n$. fluviatilis were rare (0.21\%: 2/942 larva each). Among the Culex spp., Cx. pipiens was predominating (65.68\%: 2827/4304 larva) while $C x$. nebulosus, $C x$. perexiguus and $C x$. wigglesworthi were rare (altogether 0.16\%: 7/4304 larva). Of Aedine spp., St. aegypti (=Ae. aegypti) was predominating (71.43\%: 75/105 larva) while
Am. v. arabiensis $(=$ Ae. $v$. arabiensis $)$ was uncommon (3.81\%: 4/105 larva).

The number of the reported species varied among the surveyed Governorates. The heavily infested Governorates were Muhayil and Al Namas (23 sp each out of 31 total $s p .: 74.19 \%$ ) followed by Abha (12 sp.: 38.71\%), Bishah (10 sp.: 32.26\%), Rejal Almaa (6 sp.: 19.35\%), Balqarn and Sarat Abidah (4 sp. each: 12.90\%), and Tathleth (2sp.: 6.45\%). The distribution of the species in relation to the altitude ranges of the surveyed localities is presented in Table 2 . The results indicated that mosquito larvae were more common in lowlands " $<500 \mathrm{~m} "$ and highlands ">2000 m" (23 and $25 \mathrm{sp}$., respectively out of 31 ) than in the moderately altitude areas (1100 -1200 m). All species except An. culicifacies, $C x$. arbieeni, Cx. bitaeniorhynchus, Cx. duttoni, Cx. mattinglyi, Cx. nebulosus, Cx. quinquefasciatus and Cs. longiareolata were collected in Muhayil (378-465 m). Only An. arabiensis, An. cinereus, An. dthali, Cx. bitaeniorhynchus, $C x$. laticinctus, $C x$. mimeticus, Cx. pipiens, Cx. quinquefasciatus, $C x$. simpsoni, Cx. sinaiticus, Cx. theileri, Lt. tigripes, Oc. caspius and Cs. longiareolata were reported in moderately altitude areas. All species except An. arabiensis, An. fluviatilis, An. multicolor, An. sergentii, Cx. wigglesworthi, and Am. v. arabiensis were reported in the highlands.

Results of the occurrence frequency (\%) of larvae related to presence/absence of the breeding water characteristics (Tab. 3) revealed that in general, except for Aedine spp. (altogether) the others prefer presence of algae (65-83\%), vegetation (55-64\%) and shade (67-75\%). Both Culex spp. (64\%) and Aedine spp. (75\%) prefer turbid water while Anopheles spp. (72\%) and Culiseta sp. (65\%) prefer clear water. All species prefer stagnant water $(75-100 \%)$. Each single species prefers $+/-$ of certain character: (1) Algae: most of the species prefer the presence of algae except $C x$. decens, Fr. vittatus and St. aegypti that breed only in 
water devoid of algae $(100 \%, \mathrm{P}<0.05), C x$. laticinctus prefers $(\mathrm{P}>0.05)$ absence of algae (57\%) and Cx. duttoni, Cx. mattinglyi, $C x$. mimeticus and Oc. caspius indiferentially breed $(50 \%, \mathrm{P}>0.05)$ in presence or absence of algae. (2) Aquatic vegetation: most of the species prefer presence of vegetation except Cx. simpisoni, Fr. vittatus and St. aegypti that breed only in water free of vegetation $(100 \%, \mathrm{P}<0.05), C x$. laticinctus and An. cinerius prefer $(\mathrm{P}>0.05)$ absence of vegetation (57\% and $80 \%$, respectively) than its presence and $C x$. duttoni, $C x$. mimeticus, $C x$. pipiens and Oc. caspius indiferentially breed $(50 \%, \mathrm{P}>0.05)$ in presence or absence of vegetation. (3) Shade: most of the species prefer shaded sites than those exposed to sun except $C x$. decens, Cx. simpisoni, Cx. tritaeniorhynchus, Fr. vittatus and St. aegypti that breed in water completely exposed to sun $(100 \%, \mathrm{P}<0.05), C x$. theileri prefers $(\mathrm{P}>0.05)$ sunny sites $(57 \%)$ than shaded ones and $C x$. duttoni, Cx. mattinglyi, $C x$. mimeticus, and Oc. caspius breed $(\mathrm{P}>0.05)$ in the presence or absence of shade $(50 \%)$. (4) Turbidity: most of the species prefer clear water than turbid water except $C x$. simpisoni, $C x$. tritaeniorhynchus, $C x$. wigglesworth, Fr. vittatus and Oc. caspius that breed only in turbid water $(100 \%$, $\mathrm{P}<0.05)$ and $C x$. arbieeni, $C x$. duttoni, $C x$. mimeticus, $C x$. pipiens and $C x$. salisburiensis indiferentially breed (50\%, $\mathrm{P}>0.05$ ) in presence or absence of turbidity. (5) Water movement: most of the species prefer sites having stagnant water than those having running water except $C x$. duttoni, $C x$. mimeticus and $O c$. caspius that indiferentially breed $(50 \%, \mathrm{P}>0.05)$ in stagnant or moving water.

The joint occurrence or association among the reported species was recorded. A total of 98 different forms of association were reported for the more frequent species. The different species had different ranges of associated species (Tab. 4): Cs. longiareolata had association with 15 species, both $C x$. pipiens and $C x$. tigripes had 13 species,
Cx. theileri had 12 species, An. cinereus had 10 species, An. turkhudi, Cx. laticinctus and $C x$. sinaiticus had 9 species each and $C x$. salisburensis had 8 species. Of the different forms, the common ones were An. turkhudiCx. theileri, An. turkhudi-Cx. tigripes, An. turkhudi-Cs. longiareolata, $C x$. pipiens-Cx. tigripes, $C x$. pipiens-Cs. longiareolata, $C x$. theileri-Cx. sinaiticus, $C x$. theileri-Cx. tigripes, Cx. theileri-Cs. longiareolata and Cx. tigripes-Cs. longiareolata.

All reported genera were found breeding a year round (Fig. 2) with peaks of abundance during spring months for Anopheles (14.00 larva/10 dip) and Culex (35.35 larva/10 dip) and during winter for Aedine spp. (2.94 larva/10 dip) and Cs. longiareolata (9.29 larva/ $10 \mathrm{dip}$ ).

Based on the results of the present survey and reports of the previous surveys, a complete list of mosquito fauna in Asir Region that comprises 45 species was prepared and presented in Table 5 .

\section{Discussion}

Totally, 31 species of 8 genera were reported of which Culex was the most abundant genus ( $\mathrm{ca} .55 \%$ of the reported species), followed by Anopheles (ca. 26\%), Aedine spp. (ca. 13\%), and Lutzia and Culiseta (3\% each). Similar result was obtained by Al Ahmed et al. (2010) in the adjacent Region, Najran where Culex spp. represented $54.48 \%$ followed by Anopheles (34.99\%) and Aedes (0.34\%). The wide spreading of Culex larvae may be due to the fact that they can exploit a wide variety of aquatic habitats for their development and survival, and can tolerate highly polluted aquatic environment and relatively saline water (Alahmed, 2012).

Culex pipiens (ca.39\%) and Cs. longiareolata (ca.26\%) were the most abundant of all collected larvae. Similarly of 26 larval spp. collected in Abha (Al Ahmad et al., 2011), Cx. tritaeniorhynchus (1344 larva), Cx. pipiens (1036 larva), and Cs. longiareolata (847 larva) were the common species. Of the Anopheles larvae, An. dthali 
was common (ca.40\%) in agreement with the findings of Abdoon and Alshahrani (2003) in Asir and of Al Ahmad et al. (2011) in Abha. Among the Culex spp., Cx. pipiens was predominating (ca. 66\%). Abdullah and Merdan (1995) reported that $C x$. pipiens is the most common Culicine spp. in the Southwestern Region. AI-Ali et al. (2008) in Al Madinah encountered 7 Culex spp. of which $C x$. pipiens was the most common $(59.3 \%$ adults and $60 \%$ larvae). Of the Aedine spp., St. aegypti was predominating (ca.71\%). Similarly, out of 5 Aedine spp. collected in Abha, St. aegypti (102 larva) was the most common species (Al Ahmad et al, 2011).

According to the previous surveys, 14 species were missed during the present study. These are An. (Ano.) tenebrosus Dönitz, An. (Cel.) gambiae Giles s.1, An. (Cel.) pretoriensis Theobald, An. (Cel.) rupicolus Lewis, An. (Cel.) stephensi Liston, An. (Cel.) subpictus Grassi s.1, Cx. (Cux.) sitiens Wiedmann, Cx. (Cux.) torrentium Martini, Cx. (Cux.) univittatus Theobald, Aedes (St.) unilineatus (Theobald), Oc. (Och.) caballus (Theobald), Oc. (Och.) detritus (Haliday), Cs. (Cs) subochrea Edwards and Orthopodomyia sp. (Abdullah and Merdan, 1995; Miller et al, 2002; Abdoon and Alshahrani, 2003; Godsey et al, 2003; Ahmed et al, 2011; Al Ahmad et al, 2011). Consequently, mosquito fauna of Asir Region comprises 45 species: 14 Anopheles, 20 Culex, 1 species each of Lutzia, Aedes, Aedimorphus, Fredwardsius, Stegomyia and Orthopodomyia, 3 Ochlerotatus (and 2 Culiseta.

In the present study, five of the reported species were not encountered before in Asir Region, these are: (1) Species that were reported in other Regions: An. fluviatilis in Dammam (Büttiker, 1981), Eastern Region (Wills et al, 1985; Alahmed, 2012) and Jeddah (Al Ghamdi et al, 2008) and $C x$. mattinglyi in Riyadh (Al Ahmad et al, 2011), (2) Species that were reported in the neighboring and other Regions: $C x$. arbi- eeni in Najran (AL Ahmed et al, 2010), Al Madinah (Kheir et al,2010) and Makkah (Alahmad et al, 2009), and Cx. mimeticus in Jizan, Al Bahah and Makkah (Khater et al, 2013). So that, these four species may be considered a new report in Asir Region, (3) Cx. wigglesworthi collected in Muhayil was not reported in any Region of the Kingdom so that may be considered a new record in the kingdom of Saudi Arabia

The finding that Rejal Almaa, Balqarn, Sarat Abidah and Tathleth yielded low numbers of species (2-6 sp.: ca. 7-19\%) comparable to the other Governorates (Muhayil, Al Namas and Abha, 10-23 sp: ca.32-74\%) is due to that these governorates were surveyed for short periods.

Examining the distribution of the different species in relation to altitudes of the surveyed localities revealed that mosquito larvae were more common in low- and highlands than in the moderately altitude areas. Although few species (An. cinereus, An. dthali, Cx. laticinctus, Cx. mimeticus, Cx. pipiens, Cx. simpsoni, Cx. sinaiticus, $C x$. theileri, Lt. tigripes and Oc. caspius) have no distinct altitude range and occur in all altitudes, still some species have specific ranges for example: (1) An. fluviatilis, An. multicolor, An. sergentii, Cx. wigglesworthi and Am. v. arabiensis were reported only from lowlands, (2) An. culicifacies, $C x$. arbieeni, $C x$. duttoni, $C x$. mattinglyi and $C x$. nebulosus were restricted to highlands, (3) An. turkhudi, Cx. decens, Cx. perexiguus, Cx. salisburensis, Cx. tritaeniorhynchus, Fr. vittatus and St. aegypti were reported from low- and highlands, (4) Cx. bitaeniorhynchus, Cx. quinquefasciatus and Cs. longiareolata were reported from moderately altitude areas and highlands while (5) An. arabiensis was reported from lowlands and moderately altitude areas. In only single study on this respect in Asir, Abdullah and Merdan (1995) collected An. arabiensis and $C x$. pipiens in different altitudes from sea level up to highlands, $A n$. sergentii from Red sea costal area (RSCA) 
and Muhayil $(500 \mathrm{~m})$ which is moderately elevated area while collection failed at highlands, An. multicolor at the RSCAs and also at a relatively elevated place of Tehamah Asir, Cx. quinquefaciatus from the RSCA, Cx. theileri at highlands (Najran, khamis Mushait and Al Namas, 1700-2400 m), and Ae. caspius at sea level, moderately elevated and highlands (Abha, Bihshah and Al Namas).

Mosquito larvae showed different preference for the natural characters of their breeding water, but in general with the exception of Aedine larvae (altogether), the other species prefer presence of algae, vegetation and shade and absence of turbidity (except Culex spp.). All species prefer stagnant water. Fritsch (1997) reported that the effect of sunlight or shade varies depending on the mosquito species. The favorable effect of sunlight on mosquito larval population is to the requirement of algae (favorable larval food) to sunlight. Sattler et al. (2005) indicated that in turbid breeding sites, Culicine larvae are much more likely to be present, whereas the Anopheles larvae are much more likely to be absent. The presence of floating plants and algae provide optimal breeding conditions for mosquito larvae by acting as food sources, shelter from predators and creates stagnant conditions by decreasing water movement (Greenway et al, 2003) and offering newly emerged adults and gravid mosquitoes a shaded resting site (Mutuku et $a l, 2009)$. In Egypt, most of mosquito larvae significantly prefer stagnant water (Ammar et al, 2013).

Different forms of association among mosquito larvae were observed of which 9 forms: An. turkhudi with $C x$. theileri, $C x$. tigripes and Cs. longiareolata; $C x$. pipiens with $C x$. tigripes and $C s$. longiareolata; $C x$. theileri with $C x$. sinaiticus, Cs. longiareolata, and $C x$. tigripes and $C x$. tigripes with Cs. longiareolata were the common ones. No available reports on mosquito association in any part of the kingdom except that of Abdullah and Merdan (1995) who reported several forms of association in Asir. These are An. arabiensis with $A n$. tenebrosus, $C x$. pipiens and Cx. theileri; $A n$. sergentii with $C x$. pipiens, $C x$. quinquefasciatus and Cs. subochrea; An. multicolor with $C x$. quinquefasciatus, Oc. caspius, and Cs. subochrea; Cx. pipiens with $C x$. quinquefasciatus, Cx. theileri, Oc. caspius, and Cs. subochrea; Cx. theileri with Oc. caspius and Cs. subochrea and Oc. caspius with $C x$. quinquefasciatus and $C s$. subochrea.

Mosquitoes were found breeding all year round with peaks of abundance during spring for Anopheles and Culex spp. and during winter for Aedine spp. and Cs. longiareolata, i.e. during mild and cold months almost similar to observation of Abdullah and Merdan (1995) in Asir. Ahmed et al. (2011) reported that mosquitoes in AL Ahsaa are prevalent in both winter and spring seasons, rarely encountered in summer and are found in moderation during the autumn months.

Several mosquito species of Asir Region are implicated as vectors of diseases either in Asir or in several other parts of the Kingdom. An. arabiensis is a primary vector and An. sergentii is a secondary vector responsible for malaria transmission in Asir (Al Seghayer et al, 1999; Abdoon and Alshahrani, 2003). Malaria is highly endemic in the Southwest (Jizan and Asir) where $83 \%$ of the Kingdom total cases are reported (Al Seghayer et al, 1999). Moreover, other reported Anopheles spp. in Asir has roles in malaria transmission in the other parts of the Kingdom for example: $A n$. stephensi (Eastern Province) and An. superpictus (Northern Province). In addition, An. fluviatilis and An. sergentii in the Eastern Province are considered as secondary vectors (Daggy, 1959; $\mathrm{MOH}$, 1983). Another species is of importance in malaria transmission in other countries, $A n$. multicolor, a suspected oases vector in Egypt (Kenawy et al, 1986) and North Africa 
(Zahar, 1974) and is regarded as a secondary malaria vector in some localities of Saudi Arabia (Abdoon and Alshahrani, 2003).

Culex mosquitoes, especially $C x$. pipiens and $C x$. quinquefasciatus, are the chief vectors of bancroftian filariasis, Wuchereria bancrofti in many parts of the world including the Middle East and Eastern Mediterranean countries (AI-Ali et al., 2008). The disease has been reported from the southwestern districts of the Kingdom. Omar (1996) identified $W$. bancrofti among expatriate workers from five South-East Asian countries in Abha and reported that the local $C x$. pipiens is highly susceptible to the parasite and concluded that this mosquito species may act as a potential vector of introduced bancroftian filariasis to Saudi Arabia. Al-Ali et al. (2008) found Cx. pipiens to harbor West Nile Virus (WNV) in the examined mosquitoes from Al Madinah and concluded that there is a potential danger of the transmission of WNV in Al Madinah especially by $C x$. pipiens. Miller et al. (2002) and Jupp et al. (2002) indicated that Cx. tritaeniorhynchus and Ae. v. arabiensis are the main proven vectors of RVF virus in the southern part of Saudi Arabia. In mid September 2000, RVF out-break began in Jizan and Yemen, and then extended northwards into Asir and Al Quenfadah. It was the first time to report RVF outside Africa. El-Badry and Al-Ali (2010) reported that Ae. aegypti is the primary established indigenous domestic vector of Dengue fever, which was isolated for the first time from an adult in Jeddah in 1994 (Ahmed et al, 2011) and from February 1994 via December 2002 the total proved cases were 319 (Fakeeh and Zaki, 2003). Wills et al. (1985) isolated Sindbis virus, a human pathogen causing a dengue-like illness from $C x$. univittatus in Eastern Region.

\section{Conclusion}

The outcome data showed that four species: An. fluviatilis, Cx. arbieeni, $C x$. mattinglyi and $C x$. mimeticus are considered as new report in Asir Region and Cx. wig- glesworthi recorded for the first time from the kingdom. The occurrence and prevalence of different mosquito species mainly the disease vectors in Asir carry the thread of transmission of several mosquito-borne diseases, mainly maintaing malaria and RVF transmission and introduction of other diseases as filariasis and dengue and other viruses.

\section{References}

Abdoon, A-MMO, 2004: First record of three afrotopical Culex species (Diptera: Culicidae) in Saudi Arabia. Ann. Med. Entomol. 13, 1/2:1-9.

Abdoon, A-MMO, Alshahrani, AM, 2003: Prevalence and distribution of Anopheline mosquitoes in malaria endemic areas of Asir Region, Saudi Arabia. East Mediterr. Hlth. J. 9, 3:240-7.

Abdullah, MAR, Merdan, AI, 1995: Distribution and ecology of the mosquito fauna in the southwestern Saudi Arabia. J. Egypt. Soc. Parasitol. 25, 3:815-37.

Ahmed, AM, Shaalan, EA, Aboul-Soud, MAM, Tripet, F, Al-Khedhairy, AA, 2011: Mosquito vectors survey in the Al-Ahsaa district of eastern Saudi Arabia. J. Insect Sci. 11, 176:11-9.

Alahmed, AM, 2012: Mosquito fauna (Diptera: Culicidae) of the Eastern Region of Saudi Arabia and their seasonal abundance. J. King Saud Univ. Sci. 24, 1:55-62.

Alahmed, AM, Al Kuriji, MA, Kheir, SM, 2007: Distribution and habitat of mosquito larvae (Diptera: Culicidae) in Riyadh Region, Saudi Arabia. J. King Saud Univ. (Agric. Sci.) 9, 2:3955.

Alahmed, AM, Al Kuriji, MA, Kheir, SM, Al Ahmedi, SA, Al Hatabbi, MJ, Al Gashmari, MA, 2009: Mosquito fauna (Diptera: Culicidae) and seasonal activity in Makkah Al Mukarramah Region, Saudi Arabia. J. Egypt. Soc. Parasitol. 39, 3:991-1013.

Al Ahmed, AM, Al Kuriji, MA, Kheir, SM, Al Sogoor, DAD, Salama, HAS, 2010: Distribution and seasonal abundance of mosquitoes (Diptera: Culicidae) in the Najran Region, Saudi Arabia. Studia dipterologica 17, Heft 1/2:13-27.

Al Ahmed, AM, Badjah-Hadj-Ahmed, AY, Al Othman, ZA, Sallam, MF, 2013: Identification of wild collected mosquito vectors of diseases using gas chromatography-mass spectrometry in Jazan Province, Saudi Arabia. J. Mass Spectrom. 48, 11:1170-7. 
Al Ahmad, AM, Sallam, MF, Khuriji, MA, Kheir, SM, Azari-Hamidian, S, 2011: Checklist and pictorial key to fourth-instar larvae of mosquitoes (Diptera: Culicidae) of Saudi Arabia. J. Med. Entomol. 48, 4:717-37.

AI-Ali, KH, EI-Badry, AA, Eassa, AHA, AlJuhani, A M, Al-Zubiany, SF, et al, 2008: A study on Culex species and Culex transmitted diseases in AI-Madinah AI-Munawarah, Saudi Arabia. PUJ 1, 2:101-8.

Al Ghamdi, K, Alikhan, M, Mahayoub, J, Afifi, ZI, 2008: Studies on identification and population dynamics of Anopheline mosquito from Jeddah, Saudi Arabia. Biosci. Biotech. Res. Commun. 1, 1:19-24.

Al-Seghayer, SM, Kenawy, MA, Ali, OTE, 1999: Malaria in the Kingdom of Saudi Arabia: Epidemiology and control. Sci. J. King Faisal University (Special issue), 1:6-20.

Al-Sheik, AA, 2011: Larval habitat, ecology, seasonal abundance and vectorial role in malaria transmission of Anopheles arabiensis in Jazan Region of Saudi Arabia, J. Egypt. Soc. Parasitol. 41, 3:615-34.

Ammar, SE, Kenawy, MA, Abdel-Rahman, HA, Ali, AF, Abdel-Hamid, YM, 2013: Characterization of the mosquito breeding habitats in two urban localities of Cairo Governorate, Egypt. GJBS 3, 7:268-75.

Büttiker, W, 1981: Observations on urban mosquitoes in Saudi Arabia. Fauna of Saudi Arabia, 3:472-9.

Daggy, RH, 1959: Malaria in oases of eastern Saudi Arabia. Am. J. Trop. Med. Hyg. 8, 2:22391

El-Badry, AA, Al-Ali, KH, 2010: Prevalence and seasonal distribution of dengue mosquito, Aedes aegypti (Diptera: Culicidae) in Al Madinah Al-Munawwarah, Saudi Arabia. J. Entomol. 7, 2:80-8.

El Khereji, MA, Alahmed, AM, Kheir, SM, 2007: Survey and seasonal activity of adult mosquitoes (Diptera: Culicidae) in Riyadh City, Saudi Arabia. Food Sci. Agric. Res. Center, King Saud Univ., Res. Bult., 152:5-17.

Fakeeh, M, Zaki, AM, 2001: Virologic and serologic surveillance for dengue fever in Jeddah, Saudi Arabia, 1994-1999. Am. J. Trop. Med. Hyg. 65, 6:764-7.

Fakeeh, M, Zaki, AM, 2003: Dengue in Jeddah, Saudi Arabia, 1994-2002. Bull. WHO, 27: 13-8.

Fritsch, MS, 1997: Management of Agricultural Drainage Water Quality: Health Issues Related To Drainage Water Management. CA, Madramootoo, WR, Johnston, and LS, Willardson (eds),
FAO, Natural Resources Management and Environment Department, Water Reports 13, http:// www.fao.org/docrep/W7224E.htm

Gaffigan, TV, Wilkerson, RC, Pecor, JE, Stoffer, JA, Anderson, T, 2014: Systematic Catalog of Culicidae. Walter Reed Biosystematics Unit (WRBU), http://www.mosquitocatalog. org/default.aspx.

Glick, JI, 1992: Illustrated key to the female Anopheles of southwestern Asia and Egypt (Diptera: Culicidae). Mosq. Syst. 24, 2:125-53.

Godsey, MS Jr, Abdoon, AM, Savage, HM, Al-Shahrani, AM, Al-Mazrou, Y, et al, 2003: First record of Aedes (Stegomyia) unilineatus in the Kingdom of Saudi Arabia. J. Am. Mosq. Control Assoc. 19, 1:84-6.

Greenway, M, Dale, P, Chapman, H, 2003: An assessment of mosquito breeding and control in four surface flow wetlands in tropical-subtropical Australia. Water Sci. Technol. 48, 5:249-56.

Harbach, RE, 1985: Pictorial keys to the genera of mosquitoes, subgenera of Culex and the species of Culex (Culex) occurring in southwestern Asia and Egypt, with a note on the subgeneric placement of Culex deserticola (Diptera: Culicidae). Mosq. Syst. 17, 2:83-107.

Harbach, RE, 1988: The mosquitoes of the subgenus Culex in southwestern Asia and Egypt (Diptera: Culicidae). Contributions of the American Entomological Institute 24, 1:1-240.

Hopkins, GH, 1952: Mosquitoes of the Ethiopian Region. 1- Larval Bionomics of Mosquitoes and Taxonomy of Culicinae Larvae. Printed by Order of the Trustees, Aldard \& Son Ltd., London, England.

Jupp, PG, Kemp, A, Grobbelaar, A, Leman, P, Burt, FJ, et al., 2002: The 2000 epidemic of Rift Valley fever in Saudi Arabia: mosquito vector studies. Med. Vet. Entomol. 16, 3:245-52.

Kenawy, MA, Beier, JC, El-Said, S, 1986: First record of malaria and associated Anopheles in El Gara Oasis, Egypt. J. Am. Mosq. Cont. Assoc. 2, 1:101-3.

Khan NA, Azhar, EI, El-Fiky, S, Madani, HH, Abuljadial, MA, et al, 2008: Clinical profile and outcome of hospitalized patients during first outbreak of dengue in Makkah, Saudi Arabia. Act Trop. 105, 1:39-44.

Khater, EI, Sowilem, MM, Sallam, MF, Alahmed, AM, 2013: Ecology and habitat characterization of mosquitoes in Saudi Arabia. Trop. Biomed. 30, 3:409-27.

Kheir, SM, Al Ahmed, AM, Al Kuriji, MA, Al Zubyani, SF, 2010: Distribution and seasonal activity of mosquitoes (Diptera: Culicidae) in $\mathrm{Al}$ 
Madinah Al Munwwarah Region, Saudi Arabia. J. Egypt. Soc. Parasitol. 40, 1:215-27.

Madani, TA, Al-Mazrou, YY, Al-Jeffri, MH, Mishkhas, AA, Al-Rabeah, AM, et al, 2003: Rift Valley Fever epidemic in Saudi Arabia: Epidemiological, clinical, and laboratory characteristics. Clin. Infect. Dis. 37, 8:1084-92.

Mattingly, PF, Knight, KL, 1956: The mosquitoes of Arabia. Bull. Brit. Mus. (Nat. Hist.) Entomol. 4, 3:89-141.

Miller, BR, Godsey, MS, Crabtree, MB, Savage, HM, Al-Mazrao, Y, et al, 2002: Isolation and genetic characterization of Rift Valley Fever virus from Aedes vexans arabiensis, Kingdom of Saudi Arabia. Emerg. Infect. Dis. 8, 12:1492-4.

MOH (Ministry of Health, Kingdom of Saudi Arabia) 1983: Malaria control programme in the Kingdom: Annual Report of Malaria Control Service (January-December 1982), 90 pp.

Mutuku, FM, Bayoh, MN, Hightower, AW, Vulule, JM, Gimnig, JE, et al, 2009: A supervised land cover classification of a western Kenya lowland endemic for human malaria: associations of land cover with larval Anopheles habitats. Int. J. Hlth. Geogr., 8:19-31.

Table 1: Reported mosquito species and their relative abundance in Asir Province

\begin{tabular}{|c|c|c|}
\hline \multirow[b]{2}{*}{ Species* } & \multicolumn{2}{|c|}{ No of collected larvae } \\
\hline & Total (7247) & $\%$ \\
\hline 01. Anopheles (Cellia) arabiensis Patton & 164 & 2.26 \\
\hline 02. An. (Cel.) cinereus Theobald & 170 & 2.35 \\
\hline 03. An. (Cel.) culicifacies Giles s.l. & 2 & 0.03 \\
\hline 04. An. (Cel.) dthali Patton & 378 & 5.22 \\
\hline 05. An. (Cel.) fluviatilis James & 2 & 0.03 \\
\hline 06. An. (Cel.) multicolor Cambouliu & 13 & 0.18 \\
\hline 07. An. (Cel.) sergentii Theobald & 128 & 1.77 \\
\hline 08. An. (Cel.) turkhudi Liston & 85 & 1.17 \\
\hline 09. Cx. (Culex) decens Theobald & 13 & 0.18 \\
\hline 10. Cx.(Cux.) duttoni Theobald & 43 & 0.59 \\
\hline 11. Cx.(Cux.) laticinctus Edwards & 116 & 1.60 \\
\hline 12. Cx. (Cux.) mattinglyi Knight & 8 & 0.11 \\
\hline 13. Cx. (Cux.) mimeticus Noè & 8 & 0.11 \\
\hline 14. Cx. (Cux.) perexiguus Theobald & 3 & 0.04 \\
\hline 15. Cx. (Cux.) pipiens L. & 2827 & 39.00 \\
\hline 16. Cx. (Cux.) quinquefasciatus Say & 10 & 0.14 \\
\hline 17. Cx. (Cux.) simpsoni Theobald & 25 & 0.34 \\
\hline 18. Cx. (Cux.) sinaiticus Kirkpatrik & 158 & 2.18 \\
\hline 19. Cx. (Cux.) theileri Theobald & 672 & 9.27 \\
\hline 20. Cx. (Cux.) tritaeniorhynchus Giles & 206 & 2.84 \\
\hline 21. Cx. (Culiciomyia) nebulosus Theobald, & 2 & 0.03 \\
\hline 22. Cx. (Eumelanomyia) wigglesworthi Edwards & 2 & 0.03 \\
\hline 23. Cx. (Maillotia) arbieeni Salem & 12 & 0.17 \\
\hline 24. Cx. (Maillotia) salisburiensis Theobald & 11 & 0.15 \\
\hline 25. Cx. (Oculeomyia)bitaeniorhynchus Giles & 19 & 0.26 \\
\hline 26. Lutzia (Metalutzia) tigripes (de Grandpre \& de Charmoy) & 169 & 2.33 \\
\hline 27. Aedimorphus vexans arabiensis (Patton) & 4 & 0.06 \\
\hline 28. Fredwardsius vittatus (Bigot) & 10 & 0.14 \\
\hline 29. Ochlerotatus (Oc.) caspius (Pallas) & 16 & 0.22 \\
\hline 30. Stegomyia $($ St. $)$ aegypti (L.) & 75 & 1.03 \\
\hline 31. Culiseta (Allotheobaldia) longiareolata Macquart & 1896 & 26.16 \\
\hline
\end{tabular}

* In addition to 98 Culex sp. and 3 Anopheles sp.
Omar, MS, 1996: A survey of bancroftian filariasis among South-East Asian expatriate workers in Saudi Arabia. Trop. Med. Int. Hlth. I, 2:155-60.

Sattler, MA, Mtasiwa, D, Kiama, M, Premji, Z, Tanner, M, et al, 2005: Habitat characterization and spatial distribution of Anopheles sp. mosquito larvae in Dar es Salaam (Tanzania) during an extended dry period. Malar. J. 4, 4:15.

Sebai, ZA, Morsy, TA, Zawahry, MI, 1974: A preliminary study on filariasis in Western part of Saudi Arabia. Castellania Tropenmed. Dermatol. Acron Verlag, Berlin 2, 12:263-6.

Warrell, DA, 1993: Leishmaniasis, malaria and schistosomiasis in Saudi Arabia. Saudi Med. J., 14:203-8.

Wills, WM, Jakob, WL, Francy, DB, Oertley, RE, Anani, E, et al, 1985: Sindbis virus isolations from Saudi Arabian mosquitoes. Trans R. Soc. Trop. Med. Hyg. 79, 1:63-6.

Zahar, AR, 1974: Review of the ecology of malaria vectors in the WHO Eastern Mediterranean Region. Bull. WHO 50, 5:427-40 
Table 2: Mosquito larval species in relation to elevation above sea level of surveyed areas in Asir Province

\begin{tabular}{|c|c|c|c|}
\hline Species & $\begin{array}{l}\text { Low lands: foothills } \\
\text { (Muhayil) } \\
\text { 378-465 m }\end{array}$ & $\begin{array}{l}\text { Moderately altitude: } \\
\text { (Bishah, Rejal Almaa and } \\
\text { Tathleth) 1103-1194 m }\end{array}$ & $\begin{array}{l}\text { High lands (Abha, Sarat } \\
\text { Abidah, Balqarn and Al } \\
\text { Namas) } 1770-2388 \mathrm{~m}\end{array}$ \\
\hline \multicolumn{4}{|l|}{ An. arabiensis } \\
\hline \multicolumn{4}{|l|}{ An. cinereus } \\
\hline \multicolumn{4}{|l|}{ An. culicifacies } \\
\hline \multicolumn{4}{|l|}{ An. dthali } \\
\hline \multicolumn{4}{|l|}{ An. fluviatilis } \\
\hline \multicolumn{4}{|l|}{ An. multicolor } \\
\hline \multicolumn{4}{|l|}{ An. sergentii } \\
\hline \multicolumn{4}{|l|}{ An. turkhudi } \\
\hline \multicolumn{4}{|l|}{ Cx. arbieeni } \\
\hline \multicolumn{4}{|c|}{ Cx. bitaeniorhynchus } \\
\hline \multicolumn{4}{|l|}{ Cx. decens } \\
\hline \multicolumn{4}{|l|}{ Cx. duttoni } \\
\hline \multicolumn{4}{|l|}{ Cx. laticinctus } \\
\hline \multicolumn{4}{|l|}{ Cx. mattinglyi } \\
\hline \multicolumn{4}{|l|}{ Cx. mimeticus } \\
\hline \multicolumn{4}{|l|}{ Cx. nebulosus } \\
\hline \multicolumn{4}{|l|}{ Cx. perexiguus } \\
\hline \multicolumn{4}{|l|}{ Cx. pipiens } \\
\hline \multicolumn{4}{|c|}{ Cx. quinquefasciatus } \\
\hline \multicolumn{4}{|c|}{ Cx salisburensis } \\
\hline \multicolumn{4}{|l|}{ Cx. simpsoni } \\
\hline \multicolumn{4}{|l|}{ Cx. sinaiticus } \\
\hline \multicolumn{4}{|l|}{ Cx. theileri } \\
\hline \multicolumn{4}{|c|}{ Cx. tritaeniorhynchus } \\
\hline \multicolumn{4}{|l|}{ Cx. wigglesworthi } \\
\hline \multicolumn{4}{|l|}{ Lt. tigripes } \\
\hline \multicolumn{4}{|l|}{ Am. v. arabiensis } \\
\hline \multicolumn{4}{|l|}{ Fr. vittatus } \\
\hline \multicolumn{4}{|l|}{ Oc. caspius } \\
\hline \multicolumn{4}{|l|}{ St. aegypti } \\
\hline \multicolumn{4}{|l|}{ Cs. longiareolata } \\
\hline No of species & 23 & 14 & 25 \\
\hline
\end{tabular}

Table 3: Occurrence frequencies (\%) of mosquito larvae in different characteristics of breeding habitats

\begin{tabular}{|l|l|l|l|l|l|}
\hline Genus & Algae $+/-$ & Vegetation $+/-$ & Shade $+/-$ & Turbidity $+/-$ & Water movement $+/-$ \\
\hline Anopheles & $83 / 17^{*}$ & $61 / 39$ & $67 / 33^{*}$ & $28 / 72^{*}$ & $0 / 100^{*}$ \\
\hline Culex & $70 / 30^{*}$ & $64 / 36$ & $69 / 31$ & $64 / 36$ & $18 / 82^{*}$ \\
\hline Aedes $* *$ & $25 / 75^{*}$ & $25 / 75^{*}$ & $25 / 75^{*}$ & $75 / 25^{*}$ & $25 / 75^{*}$ \\
\hline Culiseta & $65 / 35^{*}$ & $55 / 45$ & $75 / 25^{*}$ & $35 / 65^{*}$ & $20 / 80^{*}$ \\
\hline
\end{tabular}

*Significant $\mathrm{P}<0.05$, **Represented by Aedes, Aedimorphus, Fredwardsius, Ochlerotatus and Stegomyia. 
Table 4: Different forms of association among reported mosquito larvae in Asir Province (acommon forms)

\begin{tabular}{|c|c|c|c|c|c|c|c|c|c|}
\hline Associated species & 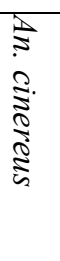 & 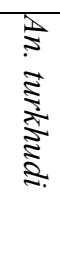 & 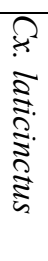 & 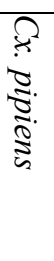 & 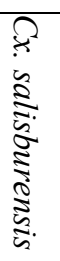 & 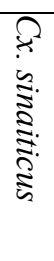 & 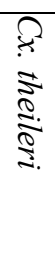 & 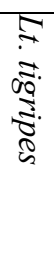 & 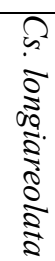 \\
\hline An. cinereus & & a & घ & घ & a & a & a & 口 & ! \\
\hline An. fluviatilis & & & & & & & - & & \\
\hline An. sergentii & & & & $\square$ & - & & & - & \\
\hline An. turkhudi & घ & & घ & $\square$ & & घ & a & घ & 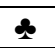 \\
\hline Cx. arbieeni & & $\square$ & & & & & & - & ! \\
\hline Cx. decens & & & & & & 口 & - & & - \\
\hline Cx. duttoni & 口 & & & $\square$ & a & & & ! & - \\
\hline Cx. laticinctus & 口 & $\mathbf{a}$ & & $\square$ & & a & - & घ & ! \\
\hline Cx. mattinglyi & & & - & & & - & - & & - \\
\hline Cx. nebulosus & - & & & - & a & & & घ & ! \\
\hline Cx. pipiens & 口 & a & ! & & a & 口 & 口 & $\$$ & 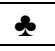 \\
\hline Cx. salisburensis & घ & & & घ & & & & घ & - \\
\hline Cx. simpsoni & & & & $\square$ & & & & & ! \\
\hline Cx. sinaiticus & घ & a & $\square$ & $\square$ & & & 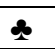 & घ & - \\
\hline Cx. theileri & - & 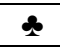 & - & $\square$ & & 2 & & $\&$ & 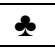 \\
\hline Cx. tritaeniorhynchus & & & & & & & $\bullet$ & & \\
\hline Cx. wigglesworthi & & $\square$ & & - & 口 & & - & - & \\
\hline Lt. tigripes & 口 & 2 & $\mathbf{\square}$ & 2 & $\mathbf{\square}$ & a & \& & & 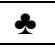 \\
\hline Oc. caspius & & & & & & & & & ! \\
\hline St. aegypti & & & $\square$ & & & & & & \\
\hline Cs. longiareolata & घ & $\stackrel{2}{2}$ & घ & 2 & घ & घ & 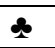 & 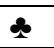 & \\
\hline No of species & 10 & 9 & 9 & 13 & 8 & 9 & 12 & 13 & 15 \\
\hline
\end{tabular}

Table 5: Mosquito fauna of Asir Province (*Not collected in this survey)

\begin{tabular}{|c|c|c|c|}
\hline Species & Asir Province & $\begin{array}{l}\text { Neigbouring Regions: } \\
\text { Jizan (J), Najran (N), Al } \\
\text { Bahah (B), Al Madinah (M) }\end{array}$ & Other Saudi Regions \\
\hline An. arabiensis & $\begin{array}{l}\text { Abdullah \& Merdan 1995, } \\
\text { Al-Seghayer et al 1999, } \\
\text { Abdoon \& Alshahrani } \\
2003\end{array}$ & $\begin{array}{l}\text { Al-Seghayer et al } 1999 \\
\text { (Western \& southern areas), } \\
\text { Khater } \text { et al } 2013(\mathrm{~J}, \mathrm{~B})\end{array}$ & $\begin{array}{l}\text { Glick 1992, Khater et al 2013, Gaffigan } \\
\text { et al } 2014\end{array}$ \\
\hline An. cinereus & Al Ahmad et al 2011 & & $\begin{array}{l}\text { Mattingly \& Knight 1956, Glick 1992, } \\
\text { Alahmed } 2012\end{array}$ \\
\hline An. culicifacies & Al Ahmad et al 2011 & Al Ahmad et al $2011(\mathrm{~N})$ & Al Ghamdi et al 2008 \\
\hline An. dthali & $\begin{array}{l}\text { Al-Seghayer et al 1999, } \\
\text { Miller et al 2002, Abdoon } \\
\& \text { Alshahrani 2003, Al } \\
\text { Ahmad et al } 2011\end{array}$ & $\begin{array}{l}\text { Al-Seghayer et al } 1999 \\
\text { (Western \& southern areas), } \\
\text { Miller et al } 2002(\mathrm{~J}), \text { Kheir } \\
\text { et al } 2010 \text { (M), Al-Sheik } \\
2011 \text { (J), Khater et al. } \\
2013(\mathrm{~J}, \mathrm{~B})\end{array}$ & $\begin{array}{l}\text { Glick } 1992 \text {, Miller et al 2002, El } \\
\text { Khereji et al 2007, Al Ghamdi et al } \\
\text { 2008, Alahmad et al 2009, Al Ahmad et } \\
\text { al 2011, Alahmad 2012, Khater et al. } \\
\text { 2013, Gaffigan et al 2014 }\end{array}$ \\
\hline An. fluviatilis & & & $\begin{array}{l}\text { Mattingly \& Knight 1956, Büttiker 1981, } \\
\text { Wills et al 1985, Glick 1992, Al- } \\
\text { Seghayer et al 1999, Al Ghamdi et al } \\
2008 \text {, Alahmed 2012, Gaffigan et al } \\
2014\end{array}$ \\
\hline $\begin{array}{l}\text { An. } \quad \text { gambiae } \\
\text { s.1* }\end{array}$ & Al Ahmad et al 2011 & Al-Sheik 2011 (J) & $\begin{array}{l}\text { Mattingly \& Knight 1956, Al Ghamdi et } \\
\text { al 2008, Alahmad et al 2009, Alahmed } \\
2012\end{array}$ \\
\hline
\end{tabular}




\begin{tabular}{|c|c|c|c|}
\hline An. multicolor & $\begin{array}{l}\text { Abdullah \& Merdan 1995, } \\
\text { Al-Seghayer et al 1999, } \\
\text { Abdoon \& Alshahrani } \\
2003 \text {, Al Ahmad et al } \\
2011\end{array}$ & $\begin{array}{l}\text { Al-Seghayer et al } 1999 \\
\text { (Wes-tern \& southern } \\
\text { areas), Al-Sheik } 2011(\mathrm{~J}, \mathrm{M})\end{array}$ & $\begin{array}{l}\text { Mattingly \& Knight 1956, Glick 1992, } \\
\text { Al-Seghayer et al 1999, Al Ghamdi et al } \\
\text { 2008, Alahmad et al 2009, A Ahmad et } \\
\text { al 2011, Alahmed 2012, Gaffigan et al } \\
2014\end{array}$ \\
\hline $\begin{array}{l}\text { An. pretoriensis } \\
*\end{array}$ & $\begin{array}{l}\text { Abdoon \& Alshahrani } \\
2003 \text {, Al Ahmad et al } \\
2011\end{array}$ & Al-Sheik 2011 (J) & $\begin{array}{l}\text { Glick 1992, El Khereji et al 2007, } \\
\text { Alahmed 2012 }\end{array}$ \\
\hline An. rupicolus* & $\begin{array}{l}\text { Al-Seghayer et al 1999, } \\
\text { Abdoon \& Alshahrani } \\
2003\end{array}$ & $\begin{array}{l}\text { Al-Seghayer et al } 1999 \\
\text { (Wes-tern \& southern } \\
\text { areas), Al-Sheik } 2011(\mathrm{~J})\end{array}$ & Glick 1992, Al Ghamdi et al 2008 \\
\hline An. sergentii & $\begin{array}{l}\text { Abdullah \& Merdan 1995, } \\
\text { Al-Seghayer et al 1999, } \\
\text { Abdoon \& Alshahrani } \\
2003 \text {, Al Ahmad et al } \\
2011\end{array}$ & 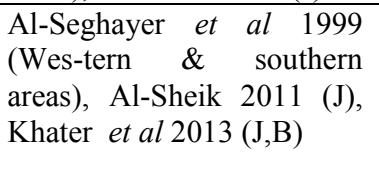 & $\begin{array}{l}\text { Mattingly \& Knight 1956, Büttiker 1981, } \\
\text { Wills et al 1985, Glick 1992, Al Ghamdi } \\
\text { et al 2008, Alahmed et al 2009, } \\
\text { Alahmed 2012, Khater et al 2013, } \\
\text { Gaffigan et al 2014 }\end{array}$ \\
\hline An. stephensi* & Al Ahmad et al 2011 & Kheir et al $2010(\mathrm{M})$ & $\begin{array}{l}\text { Mattingly \& Knight 1956, Büttiker 1981, } \\
\text { Glick 1992, Al-Seghayer et al 1999, El } \\
\text { Khereji et al 2007, Al Ghamdi et al } \\
2008 \text {, Alahmed et al 2009, Alahmed } \\
2012\end{array}$ \\
\hline An. subpictus* & Al Ahmad et al 2011 & Kheir et al $2010(\mathrm{M})$ & $\begin{array}{l}\text { Al Ghamdi et al 2008, Alahmad et al } \\
\text { 2009, Alahmed } 2012\end{array}$ \\
\hline An. tenebrosus* & Abdullah \& Merdan 1995 & & $\begin{array}{l}\text { Mattingly \& Knight 1956, Wills et al } \\
\text { 1985, Al-Seghayer et al 1999, Al Ahmad } \\
\text { et al 2011, Alahmed 2012, Gaffigan et al } \\
2014\end{array}$ \\
\hline An. turkhudi & $\begin{array}{l}\text { Al-Seghayer et al 1999, } \\
\text { Abdoon \& Alshahrani } \\
2003 \text {, Al Ahmad et al } \\
2011\end{array}$ & $\begin{array}{l}\text { Al-Seghayer et al } 1999 \\
\text { (Wes-tern \& southern } \\
\text { areas), Al-Sheik } 2011(\mathrm{~J}, \mathrm{M})\end{array}$ & $\begin{array}{l}\text { Mattingly \& Knight 1956, Glick 1992, } \\
\text { Al Ghamdi et al 2008, Alahmed et al } \\
\text { 2009, Gaffigan et al } 2014\end{array}$ \\
\hline Cx. arbieeni & & $\begin{array}{l}\text { AL Ahmed et al } 2010(\mathrm{~N}) \text {, } \\
\text { Kheir et al } 2010(\mathrm{M})\end{array}$ & Alahmed et al 2009 \\
\hline $\begin{array}{l}\text { Cx.. } \\
\text { bitaeniorhynchu } \\
\text { s }\end{array}$ & Abdoon 2004 & & t al 2014 \\
\hline Cx. decens & $\begin{array}{l}\text { Abdoon 2004, Ahmed et } \\
\text { al } 2011\end{array}$ & AI-Ali et al $2008(\mathrm{M})$ & Gaffigan et al 2014 \\
\hline Cx. duttoni & Abdoon 2004 & $\begin{array}{l}\text { AI-Ali et al } 2008(\mathrm{M}) \text {, } \\
\text { Khater et al } 2013(\mathrm{~J}, \mathrm{~B})\end{array}$ & Khater et al 2013, Gaffigan et al 2014 \\
\hline Cx. laticinctus & Al Ahmad et al 2011 & Kheir et al $2010(\mathrm{M})$ & $\begin{array}{l}\text { Mattingly \& Knight 1956, Harbach } \\
\text { 1985, El Khereji et al 2007, Alahmed et } \\
\text { al 2009, Alahmed 2012, Gaffigan et al } \\
2014\end{array}$ \\
\hline Cx. mattinglyi & & & $\begin{array}{l}\text { Mattingly \& Knight 1956, Harbach } \\
\text { 1985, Al Ahmad et al 2011, Gaffigan et } \\
\text { al 2014 }\end{array}$ \\
\hline Cx. mimeticus & & Khater et al $2013(\mathrm{~J}, \mathrm{~B})$ & $\begin{array}{l}\text { Harbach 1985, Khater et al 2013, } \\
\text { Gaffigan et al 2014 }\end{array}$ \\
\hline Cx. nebulosus & Miller et al 2002 & Miller et al $2002(\mathrm{~J})$ & Büttiker 1981, Miller et al 2002 \\
\hline Cx. perexiguus & Al Ahmad et al 2011 & Kheir et al 2010 (M) & $\begin{array}{l}\text { Harbach 1985, El Khereji et al 2007, } \\
\text { Alahmed et al 2009, Ahmed et al 2011, } \\
\text { Alahmed 2012, Gaffigan et al } 2014\end{array}$ \\
\hline Cx.pipiens & $\begin{array}{l}\text { Abdullah \& Merdan 1995, } \\
\text { Miller et al 2002, Al } \\
\text { Ahmad et al } 2011\end{array}$ & $\begin{array}{l}\text { Miller et al } 2002(\mathrm{~J}), \mathrm{AI}-\mathrm{Ali} \\
\text { et al } 2008(\mathrm{M}), \text { Kheir et al } \\
2010(\mathrm{M})\end{array}$ & $\begin{array}{l}\text { Mattingly \& Knight 1956, Harbach } \\
\text { 1985, Wills et al 1985, Jupp et al 2002, } \\
\text { Miller et al 2002, Al Ahmed et al 2009, } \\
\text { Al Ahmad et al 2011, Alahmed 2012, El } \\
\text { Khereji et al 2007, Gaffigan et al 2014 }\end{array}$ \\
\hline $\begin{array}{l}\text { Cx. } \\
\text { quinquefasciatu } \\
\text { S }\end{array}$ & $\begin{array}{l}\text { Abdullah \& Merdan 1995, } \\
\text { Al Ahmad et al } 2011\end{array}$ & $\begin{array}{l}\text { AI-Ali et al } 2008(\mathrm{M}) \\
\text { Kheir et al } 2010(\mathrm{M}) \text {, } \\
\text { Khater et al } 2013(\mathrm{~J}, \mathrm{~B})\end{array}$ & $\begin{array}{l}\text { Harbach 1985, Wills et al 1985, El } \\
\text { Khereji et al 2007, Alahmed et al 2009, } \\
\text { Alahmed 2012, Khater et al. 2013, } \\
\text { Gaffigan et al 2014 }\end{array}$ \\
\hline$C x$. & Miller et al 2002 & Miller et al $2002(\mathrm{~J})$ & Miller et al 2002 \\
\hline
\end{tabular}




\begin{tabular}{|c|c|c|c|}
\hline \multicolumn{4}{|l|}{ salisburiensis } \\
\hline Cx. simpsoni & Al Ahmad et al 2011 & Kheir et al $2010(\mathrm{M})$ & $\begin{array}{l}\text { E1 Khereji et al 2007, Alahmed et al } \\
\text { 2009, Alahmed } 2012\end{array}$ \\
\hline Cx. sinaiticus & Al Ahmad et al 2011 & & $\begin{array}{l}\text { Mattingly \& Knight 1956, Harbach } \\
\text { 1985, El Khereji et al 2007, Alahmed et } \\
\text { al 2009, Gaffigan et al 2014 }\end{array}$ \\
\hline Cx. sitiens* & Al Ahmad et al 2011 & & $\begin{array}{l}\text { Mattingly \& Knight 1956, Harbach } \\
\text { 1985, Gaffigan et al } 2014\end{array}$ \\
\hline Cx. theileri & Abdullah \& Merdan 1995 & $\begin{array}{l}\text { Kheir et al } 2010(\mathrm{M}), \mathrm{Al} \\
\text { Ahmad et al } 2011(\mathrm{~N}) \text {, } \\
\text { Khater et al } 2013(\mathrm{~J}, \mathrm{~B})\end{array}$ & $\begin{array}{l}\text { Harbach 1985, Büttiker 1981, El Khereji } \\
\text { et al 2007, Alahmed et al 2009, } \\
\text { Gaffigan et al } 2014\end{array}$ \\
\hline Cx. torrentium* & Ahmed et al 2011 & & Alahmed 2012 \\
\hline $\begin{array}{l}\text { Cx. } \\
\text { tritaeniorhynch } \\
\text { us }\end{array}$ & $\begin{array}{l}\text { Miller et al 2002, Al } \\
\text { Ahmad et al } 2011\end{array}$ & $\begin{array}{l}\text { Miller et al } 2002(\mathrm{~J}) \text {, Kheir } \\
\text { et al } 2010(\mathrm{M}) \text {, Khater et al } \\
2013(\mathrm{~J}, \mathrm{~B})\end{array}$ & $\begin{array}{l}\text { Mattingly \& Knight } 1956 \text {, Harbach1985, } \\
\text { Wills et al 1985, Jupp et al 2002, Miller } \\
\text { et al 2002, El Khereji et al 2007, } \\
\text { Alahmed et al 2009, Alahmed 2012, } \\
\text { Khater et al 2013, Gaffigan et al } 2014\end{array}$ \\
\hline Cx. univittatus* & Al Ahmad et al 2011 & Kheir et al 2010 ( M) & $\begin{array}{l}\text { Wills et al 1985, El Khereji et al } 2007 \\
\text {,Alahmed et al 2009, Alahmed } 2012\end{array}$ \\
\hline \multicolumn{4}{|l|}{$\begin{array}{l}\text { Cx. } \\
\text { wigglesworthi }\end{array}$} \\
\hline Lt. tigripes & Al Ahmad et al 2011 & & $\begin{array}{l}\text { Mattingly \& Knight 1956, Alahmed et al } \\
2009 \text { as Cx. tig... }\end{array}$ \\
\hline Ae. unilineatus* & $\begin{array}{l}\text { Miller et al 2002, Godsey } \\
\text { et al } 2003\end{array}$ & Miller et al $2002(\mathrm{~J})$ & Miller et al 2002, Gaffigan et al 2014 \\
\hline $\begin{array}{l}\text { Am. vexans } \\
\text { arabiensis }\end{array}$ & $\begin{array}{l}\text { Miller et al 2002, } \mathrm{Al} \\
\text { Ahmad et al } 2011\end{array}$ & Miller et al $2002(\mathrm{~J})$ & $\begin{array}{l}\text { Mattingly \& Knight 1956, Miller et al } \\
\text { 2002, AI-Ali et al 2008, Kheir et al } \\
\text { 2010, Gaffigan et al 2014 }\end{array}$ \\
\hline Fr. vittatus & $\begin{array}{l}\text { Miller et al 2002, Al } \\
\text { Ahmad et al } 2011\end{array}$ & Miller et al $2002(\mathrm{~J})$ & $\begin{array}{l}\text { Jupp et al 2002, Miller et al 2002, } \\
\text { Gaffigan et al 2014 }\end{array}$ \\
\hline Oc. caballus* & Ahmed et al 2011 & & Juppet al 2002 \\
\hline Oc. caspius & $\begin{array}{l}\text { Abdullah \& Merdan 1995, } \\
\text { Al Ahmad et al } 2011\end{array}$ & Kheir et al $2010(\mathrm{M})$ & $\begin{array}{l}\text { Mattingly \& Knight 1956, Büttiker 1981, } \\
\text { Wills et al 1985, Jupp et al 2002, El } \\
\text { Khereji et al 2007, Alahmed et al 2009, } \\
\text { Ahmed et al 2011, Alahmed 2012, } \\
\text { Gaffigan et al } 2014\end{array}$ \\
\hline Oc. detritus* & Al Ahmad et al 2011 & & \\
\hline St. aegypti & $\begin{array}{l}\text { Miller et al 2002, } \mathrm{Al} \\
\text { Ahmad et al } 2011\end{array}$ & $\begin{array}{l}\text { Miller et al } 2002(\mathrm{~J}) \text {, El- } \\
\text { Badry \& Al-Ali } 2010(\mathrm{M}) \text {, } \\
\text { Kheir et al } 2010 \text { (M), } \\
\text { Khater et al } 2013(\mathrm{~J}, \mathrm{~B})\end{array}$ & $\begin{array}{l}\text { Mattingly \& Knight 1956, Miller et al } \\
2002 \text {, Alahmed et al 2009, Khater et al. } \\
2013\end{array}$ \\
\hline $\begin{array}{l}\text { Cs. } \\
\text { longiareolata }\end{array}$ & Al Ahmad et al 2011 & Kheir et al 2010 ( M) & $\begin{array}{l}\text { Mattingly \& Knight } 1956 \text {, Wills et al } \\
\text { 1985, El Khereji et al 2007, Alahmed et } \\
\text { al 2009, Alahmed } 2012\end{array}$ \\
\hline Cs. subochrea* & Abdullah \& Merdan 1995 & & $\begin{array}{l}\text { Al Ahmad et al 2011, Gaffigan et al } \\
2014\end{array}$ \\
\hline $\begin{array}{l}\text { Orthopodomyia } \\
\text { sp.* }\end{array}$ & Ahmed et al 2011 & & \\
\hline
\end{tabular}




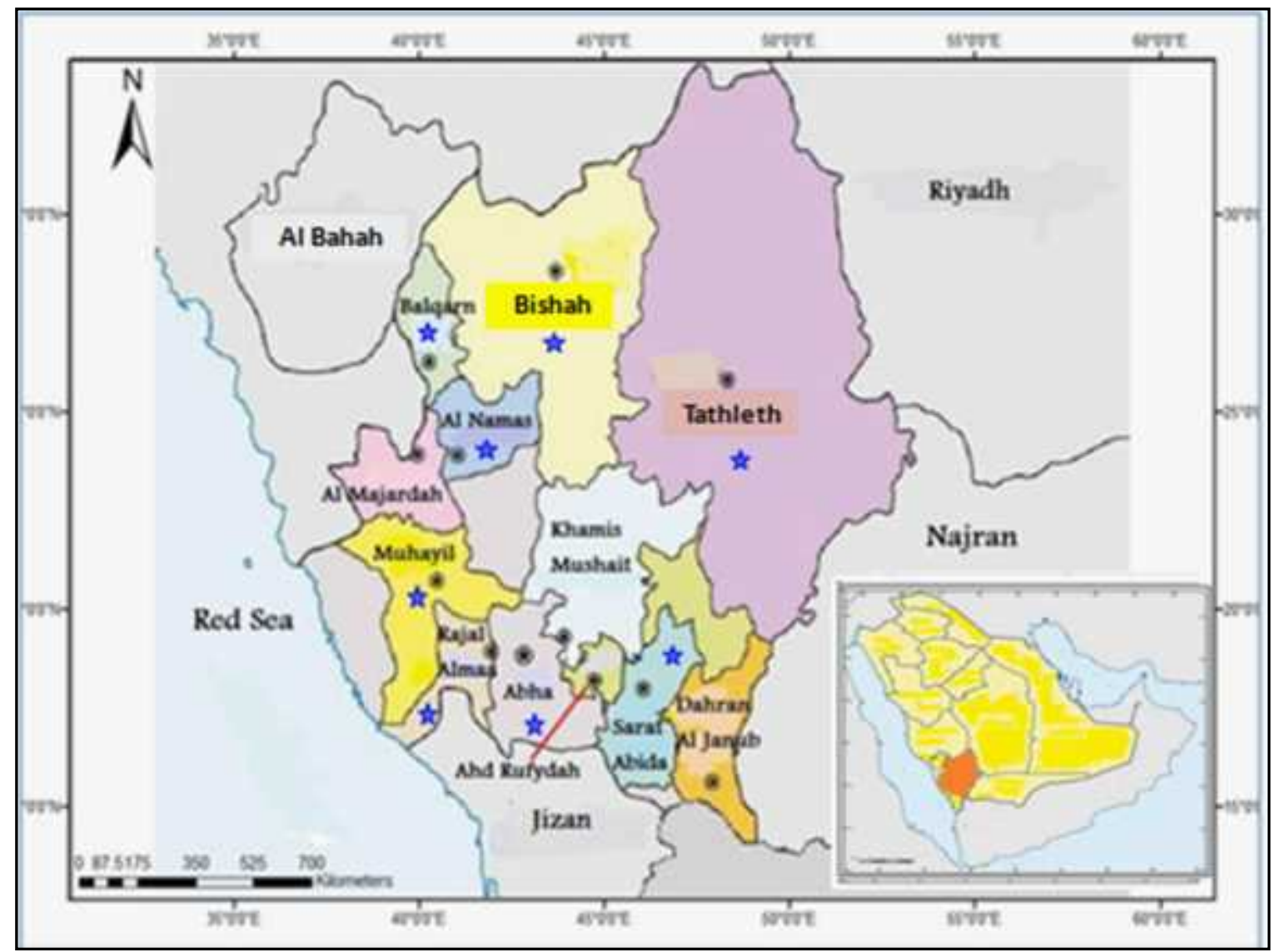

Fig. 1: Map of Asir Province showing surveyed Governorates

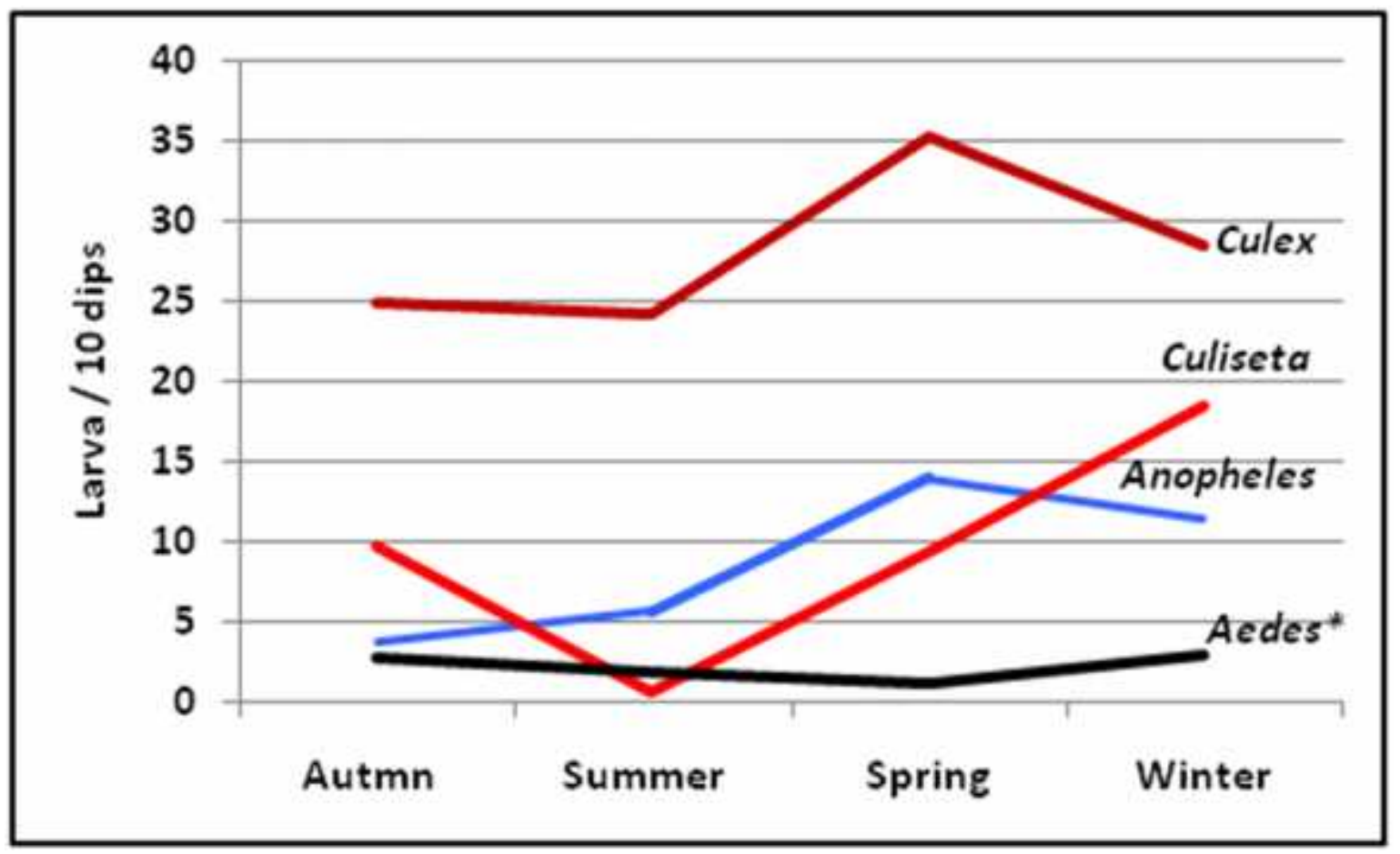

Fig. 2: Seasonal abundance of mosquito larvae in Asir Province (*Represented by Aedes, Aedimorphus, Fredwardsius, Ochlerotatus and Stegomyia) 